\title{
PLASMA TESTOSTERONE LEVELS IN RELATION TO MUSTH AND SEXUAL ACTIVITY IN THE MALE ASIATIC ELEPHANT, ELEPHAS MAXIMUS
}

\author{
M. R. JAINUDEEN, ${ }^{*}$ C. B. KATONGOLE $\dagger$ AND R. V. SHORT $†$ \\ * Faculty of Veterinary Science, University of Ceylon, Peradeniya, Ceylon, \\ tDepartment of Veterinary Clinical Studies, Madingley Road, Cambridge, and \\ $\ddagger A R C$ Unit of Reproductive Physiology and Biochemistry, 307 Huntingdon Road, \\ Cambridge
}

\section{(Received 6th August 1971, accepted 21st September 1971)}

\begin{abstract}
Summary. Testosterone was measured in the peripheral blood plasma of eleven male Asiatic elephants, using a competitive protein-binding assay. When the animals showed no signs of musth, the testosterone levels were low $(<0.2$ to $1.4 \mathrm{ng} / \mathrm{ml})$; as they began to come into musth and the temporal glands started to enlarge, the testosterone levels rose $(4 \cdot 3$ to $13.7 \mathrm{ng} / \mathrm{ml}$ ), and when the animals were in full musth, with discharging temporal glands and an aggressive temperament, the levels were extremely high (29.6 to $65.4 \mathrm{ng} / \mathrm{ml}$ ). Musth may therefore be comparable to the rutting behaviour of some seasonally breeding mammals, although, in the elephant, there is some indication that it may be induced by sexual activity.
\end{abstract}

\section{INTRODUCTION}

Captive male Asiatic elephants, Elephas maximus, periodically show the phenomenon of 'musth' which is characterized by a disobedient and aggressive temperament. There is also enlargement and discharge from the temporal glands and a continuous dribble of urine from the penis (Plate 1). Over $90 \%$ of adult bull elephants in good physical condition will come into musth once a year, and may remain in musth for 2 to 3 months at a time (Jainudeen, McKay \& Eisenberg, 1972). During this period, they are too dangerous to handle so they have to be chained up and hand-fed at great expense to their owners. Musth can occur at any time of the year but, in Ceylon, it is commonest in January-April and August-November. It is popularly believed that musth is a form of sexual activity, although bull elephants will still mate quite normally when not in musth (Jainudeen, Eisenberg \& Tillakeratne, 1971).

This paper presents an attempt to relate changes in the blood testosterone levels to the onset of musth and the period of aggressive behaviour.

Animals

\section{MATERIALS AND METHODS}

The study concerned eleven working bull elephants in Ceylon, whose ages 
ranged from 21 to 45 years (see Table 1). All the animals had previously been in musth at least once, and their behavioural status at the time of blood sampling was categorized as follows:

non-musth $=$ interval between periods of musth;

pre-musth = first stage of musth, enlargement of temporal glands;

full musth = second stage of musth, secretion from temporal glands and aggressive behaviour;

post-musth $=$ period immediately after musth.

TABLE 1

PERIPHERAL PLASMA TESTOSTERONE LEVELS IN MALE ASIATIC ELEPHANTS

\begin{tabular}{|c|c|c|c|c|}
\hline $\begin{array}{c}\text { Elephant } \\
\text { no. }\end{array}$ & $\underset{\text { (years) }}{\text { Age }}$ & $\begin{array}{l}\text { Date of blood } \\
\text { collection }\end{array}$ & $\begin{array}{l}\text { Stage of } \\
\text { musth }\end{array}$ & $\begin{array}{c}\text { Testosterone } \\
\text { (ng/ml plasma })\end{array}$ \\
\hline 1 & 25 & $\begin{array}{l}\text { February } 1969 \\
\text { March } 1970 \\
\text { April } 1970\end{array}$ & $\begin{array}{l}\text { Full musth } \\
\text { Pre-musth } \\
\text { Pre-musth }\end{array}$ & $\begin{array}{r}61.9 \\
11.9 \\
4.3\end{array}$ \\
\hline 2 & 35 & October 1969 & Post-musth & $1 \cdot 2$ \\
\hline 4 & 23 & $\begin{array}{l}\text { January } 1970 \\
\text { March } 1970 \\
\text { April } 1970 \\
\text { August } 1970\end{array}$ & $\begin{array}{l}\text { Full musth } \\
\text { Full musth } \\
\text { Post-musth } \\
\text { Non-musth }\end{array}$ & $\begin{array}{r}33.0 \\
33.9 \\
<0.2 \\
1.1\end{array}$ \\
\hline 7 & 22 & $\begin{array}{l}\text { December } 1969 \\
\text { January } 1970 \\
\text { March } 1970 \\
\text { April } 1970\end{array}$ & $\begin{array}{l}\text { Pre-musth } \\
\text { Pre-musth } \\
\text { Full musth } \\
\text { Full musth }\end{array}$ & $\begin{array}{l}12 \cdot 8 \\
13 \cdot 7 \\
65 \cdot 4 \\
55 \cdot 2\end{array}$ \\
\hline 8 & 30 & February 1970 & Full musth & $29 \cdot 6$ \\
\hline 9 & 38 & February 1970 & Non-musth & 0.2 \\
\hline 10 & 45 & $\begin{array}{l}\text { December } 1969 \\
\text { February } 1970 \\
\text { November } 1970\end{array}$ & $\begin{array}{l}\text { Non-musth } \\
\text { Non-musth } \\
\text { Non-musth }\end{array}$ & $\begin{array}{r}<0.2 \\
1.4 \\
0.9\end{array}$ \\
\hline 11 & 21 & $\begin{array}{l}\text { December } 1969 \\
\text { January } 1970 \\
\text { April } 1970\end{array}$ & $\begin{array}{l}\text { Non-musth } \\
\text { Non-musth } \\
\text { Non-musth }\end{array}$ & $\begin{array}{r}0.2 \\
1.2 \\
<0.2\end{array}$ \\
\hline 12 & 30 & April 1970 & Non-musth & 0.9 \\
\hline 13 & 25 & July 1970 & Full musth & 33.9 \\
\hline 14 & 37 & August 1970 & Non-musth & 0.9 \\
\hline
\end{tabular}

Elephants 1, 2, 4, 7 and 8 were used as stud males for serving females in oestrus, and they all came into musth during the course of the mating period.

\section{Collection of blood}

The animals were made to lie down on their sides by their mahouts, and $25 \mathrm{ml}$ of blood were withdrawn from one of the large veins on the back of the ear, and transferred to a heparinized bottle. The blood was stored on ice and transported within $2 \mathrm{hr}$ of collection to the laboratory, where the plasma was separated by centrifugation and subsequently stored at $-20^{\circ} \mathrm{C}$.

Difficulties were encountered in obtaining blood from the animals in the second stage of musth but, when they were fettered by chains to strong posts, their mahouts were able to restrain them sufficiently to allow the blood to be 
collected. One elephant (No. 13) broke his chains and ran amok. He was recaptured after immobilization with Etorphine (Reckitt \& Sons), and blood was collected whilst he was under the influence of the drug (Jainudeen, 1970).

The plasma samples were packed in dry ice and flown to Cambridge. On arrival, one consignment was still frozen but the other was just beginning to thaw. Testosterone appears to be relatively stable for some hours in plasma kept at room temperature.

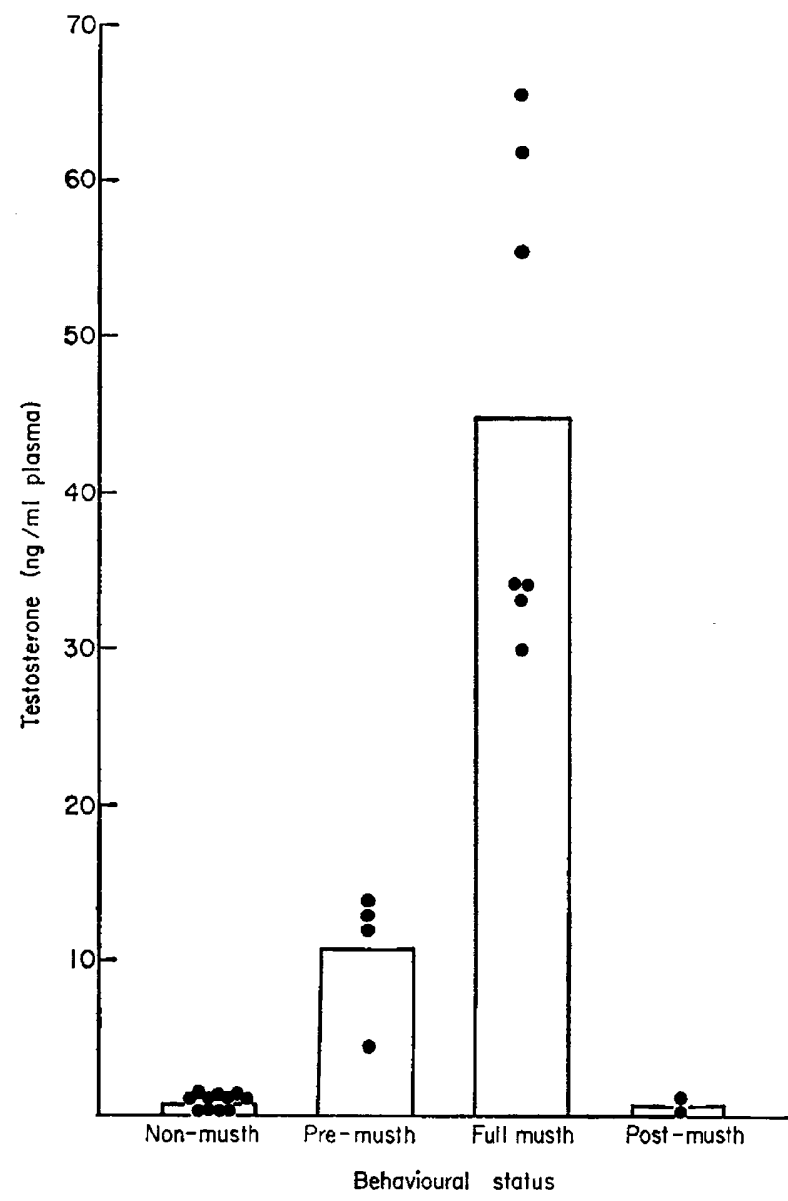

TeXT-pIG. 1. Histogram showing mean and range of blood testosterone values in various stages of musth in the Asiatic elephant.

\section{Testosterone assays}

Testosterone was measured by the competitive protein-binding procedure described by Katongole (1971), using human late-pregnancy plasma as the source of the binding protein.

\section{RESULTS}

The results are shown in Table 1 and Text-fig. 1. Testosterone was measured in 
twenty-three samples of blood from the eleven elephants, and the concentrations ranged from 0.2 to $65.4 \mathrm{ng} / \mathrm{ml}$. They were consistently low in the twelve samples collected during the non-musth phase $(0.2$ to $1.4 \mathrm{ng} / \mathrm{ml})$, elevated in the pre-musth phase $(4.3$ to $13.7 \mathrm{ng} / \mathrm{ml})$, and extremely high in the full musth phase $(29.6$ to $65.4 \mathrm{ng} / \mathrm{ml})$. At the end of musth, the levels returned to the baseline values found in the musth phase within 5 to 7 days. Elephants 11 and 14 did not come into musth at all, probably because of their poor physical condition, and their testosterone levels were consistently low.

Detailed observations were made on the sexual behaviour of the five males used for teasing and serving females in oestrus. At the beginning of the testing period, they were all in the non-musth phase although they copulated readily with oestrous females. Within 2 months, they showed evidence of temporal gland enlargement and entered the pre-musth phase. Although their mating behaviour was unaltered, they showed frequent erection of the penis when at rest, and masturbated by striking the erect penis against the belly.

As they progressed into the second stage of musth, the quantity of temporal gland secretion and the intensity of their aggressive behaviour increased daily, and teasing had to be discontinued as they became too dangerous to handle. The pattern of urination also changed; in the non-musth and pre-musth phases, the penis was usually protruded from its sheath during urination but, during the full musth phase, a more or less continuous dribble of urine occurred whilst the penis was still in the sheath (see Plate 1). At the height of musth, however, erection and masturbation seldom occurred.

Once the urination pattern had returned to normal and the temporal gland had subsided, the animals began to respond to their mahout's commands, and returned to their normal working routine in a few days.

\section{DISGUSSION}

The results of this study strongly suggest that musth is associated with and possibly caused by a marked increase in testicular testosterone secretion. An indication that it may also be induced by sexual activity is derived from the fact that musth occurred 2 to 5 months earlier than was expected in bull elephants used repeatedly for teasing and mating oestrous cows. The aggressive behaviour seen during musth may be comparable to the androgen-induced aggression of rats, mice and red deer (Sigg, Day \& Colombo, 1966; Bronson \& Desjardins, 1970; Lincoln, Youngson \& Short, 1970), and we have recently shown that sexual stimulation is an effective way of raising the blood LH and testosterone levels in bulls (Katongole, Naftolin \& Short, 1971). Musth presents considerable problems to anyone who keeps male Asiatic elephants in captivity, and it might be possible to prevent it by inhibiting testicular activity with oestrogen, or an antiandrogen such as cryproterone.

The blood testosterone levels during musth are extremely high $(29.6$ to $65.4 \mathrm{ng} / \mathrm{ml}$ ) and in excess of the maximal values encountered in men, bulls, rams and stallions (Katongole et al., 1971, and unpublished observations), whereas the values during the non-musth and pre-musth phases are comparable to those in other species. In the African elephant, Loxodonta africana, testicular 


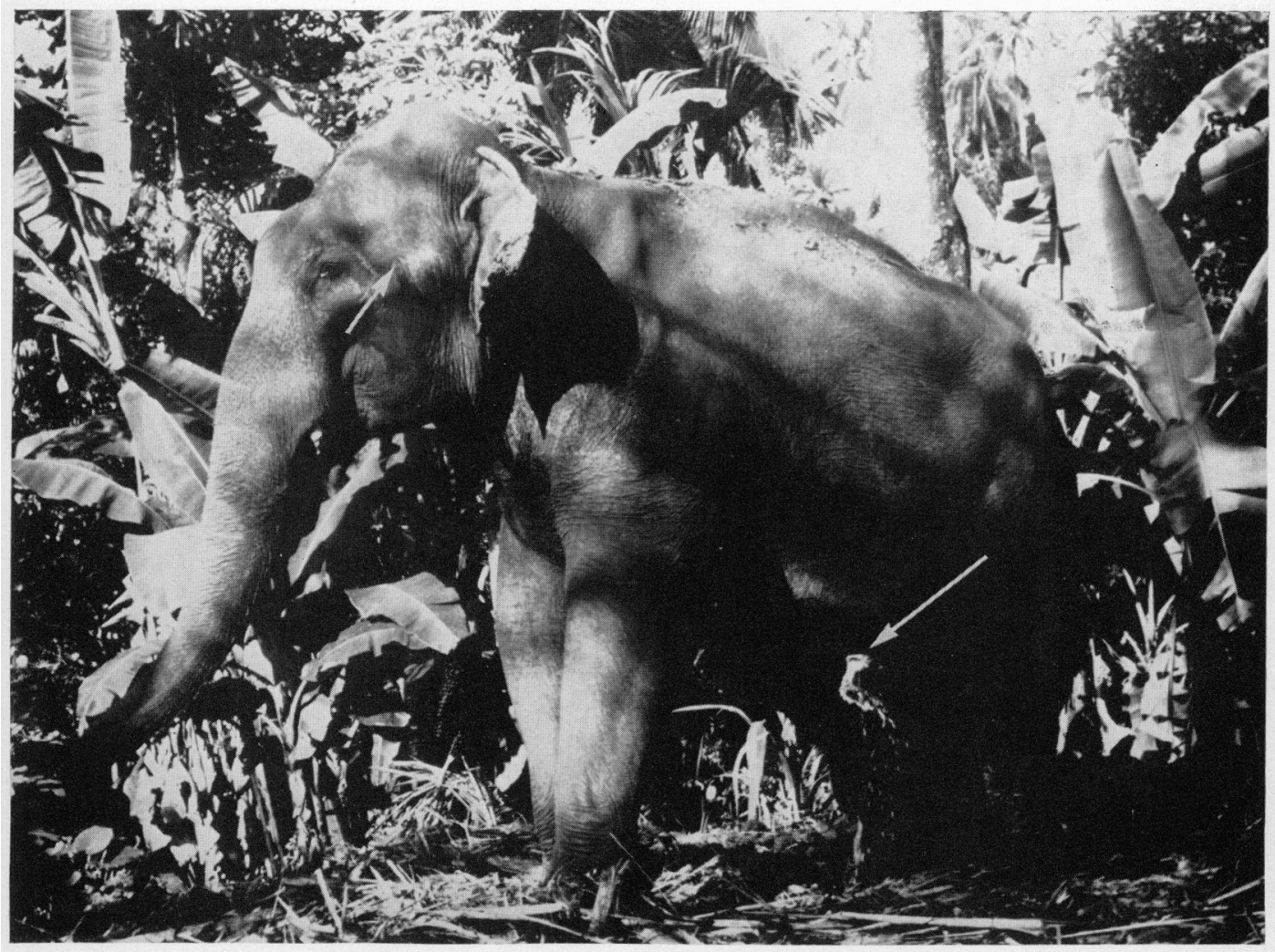

Sriatic elephatat bull in musth. The animal is fastened to stout trees by chains round its front and hind legs (nol visible, and is showing sone discharge from the temponal gland

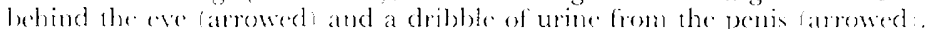


testosterone concentrations are extremely variable ( 3 to $490 \mu \mathrm{g} / 100 \mathrm{~g}$ testis), which may be an indication of periodic increases in testicular activity in this species also (Short, Mann \& Hay, 1967; Buss \& Johnson, 1967). Musth has never been recorded in the African elephant. This may be because it is difficult to detect in the wild, but aggressive behaviour has not even been observed in the few adult male African elephants that have been kept in captivity (Dittrich, personal communication).

It is clear that, in the African elephant, the secretion of the temporal gland bears no relation to sexual activity; not only can one find active secretion in females and immature calves, but the gland can be made to discharge at a moment's notice if the animals are excited or frightened (Short et al., 1967). In the Asiatic elephant, on the other hand, temporal gland secretion only occurs in adult males during musth; the secretion is almost unknown in females (Eisenberg, McKay \& Jainudeen, 1971; Jainudeen et al., 1972). Although the histological appearance of the temporal gland is similar in the two species, the factors that cause it to secrete appear to be completely different.

\section{ACKNOWLEDGMENTS}

This work was partly financed by a grant from the Smithsonian Institution, Washington, D.C., to $\mathrm{Dr}$ J. F. Eisenberg; we are particularly grateful to $\mathrm{Mr}$ Lynn Dasenaike and Mr A. W. G. Seneviratna for allowing us to take blood samples from their elephants, and to Dr L. Dittrich for information about his male African elephants in Hannover Zoo.

\section{REFERENCES}

Bronson, F. H. \& Desjardins, C. (1970) Neonatal androgen administration and adult aggressiveness in female mice. Gen. comp. Endocr. 15, 320.

Buss, I. O. \& Johnson, O. W. (1967) Relationship of Leydig cell characteristics and intratesticular testosterone levels to sexual activity in the African elephant. Anat. Rec. 157, 191.

Eisenberg, J. F., McKay, G. M. \& JainudeEn, M. R. (1971) Reproductive behaviour of the Asiatic elephant. Behaviour, 34, 193.

JAINUDEEN, M. R. (1970) The use of etorphine hydrochloride for restraint of a domesticated elephant (Elephas maximus). F. Am. vet. med. Ass. 157, 624.

Jainudeen, M. R., Eisenberg, J. F. \& Tilakeratne, N. (1971) Oestrous cycle of the Asiatic elephant, Elephas maximus, in captivity. F. Reprod. Fert. 27, 321.

JAinudeen, M. R., MCKAy, G. M. \& Ersenberg, J. F. (1972) Observations on musth in the domesticated Asiatic elephant. Mammalia, (in press).

Katongole, C. B. (1971) A competitive protein binding assay for testosterone in the plasma of the bull and the ram. F. Endocr. 51, 303.

Katongole, C. B., NAFrolin, F. \& SHORt, R. V. (1971) Relationship between blood levels of luteinizing hormone and testosterone in bulls, and the effects of sexual stimulation. F. Endocr. 50, 457.

Lincoln, G. A., Youngson, R. W. \& Short, R. V. (1970) The social and sexual behaviour of the red deer stag. F. Reprod. Fert., Suppl. 11, 71.

Short, R. V., MANn, T. \& HAy, M. F. (1967) Male reproductive organs of the African elephant, Loxodonta africana. 7. Reprod. Fert. 13, 517.

SIGG, E. B., DAY, C. A. \& ColomBo, C. (1966) Endocrine factors in isolation-induced aggressiveness in rodents. Endocrinology, 78, 679 . 